\title{
Increase in consumption of alcohol-based hand rub in German acute care hospitals over a 12 year period
}

Tobias Siegfried Kramer ${ }^{1,2,3^{*}+}$ (D) Janine Walter ${ }^{1,2,3 \dagger}$, Christin Schröder ${ }^{1,2}$, Michael Behnke ${ }^{1,2}$, Jörg Clausmeyer ${ }^{1,2}$, Christiane Reichardt ${ }^{1,2,3}$, Petra Gastmeier ${ }^{1,2,3}$ and Karin Bunte ${ }^{1,2,3}$

\begin{abstract}
Background: Hand hygiene plays a crucial role in the transmission of pathogens and the prevention of healthcareassociated infections. In 2007, a voluntary national electronic surveillance tool for the documentation of consumption of alcohol-based hand rub (AHC) was introduced as a surrogate for hand hygiene compliance (HANDKISS) and for the provision of benchmark data as feedback.

The aim of the study was to determine the trend in alcohol-based hand rub consumption between 2007 and 2018.

Materials and methods: In this cohort study, AHC and patient days (PD) were documented on every ward in participating hospitals by trained local staff. Data was collected and validated in HAND-KISS. Intensive care units (ICU), intermediate care units (IMC), and regular wards (RW) that provided data during the study period between 2007 until 2018 were included into the study.

Results: In 2018, 75.2\% of acute care hospitals in Germany ( $n=1.460)$ participated. On ICUs ( $n=1998)$ mean AHC increased 1.74 fold $(95 \% \mathrm{Cl} 1.71,1.76 ; p<.0001)$ from $79.2 \mathrm{ml} / \mathrm{PD}$ to $137.4 \mathrm{ml} / \mathrm{PD}$. On IMCs $(n=475)$ AHC increased 1.69 fold $(95 \% \mathrm{Cl} 1.60,1.79 ; p<.0001)$ from $41.4 \mathrm{ml} / \mathrm{PD}$ to $70.6 \mathrm{ml} / \mathrm{PD} . . \mathrm{On} \mathrm{RWs}(n=14,857) \mathrm{AHC}$ was $19.0 \mathrm{ml} / \mathrm{PD}$ in 2007 and increased 1.71 fold $(95 \% \mathrm{Cl} 1.70,1.73 ; p<.0001)$ to $32.6 \mathrm{ml} / \mathrm{PD}$ in 2018.

Conclusions: AHC in German hospitals increased on all types of wards during the past 12 years. Surveillance of $\mathrm{AHC}$ is widely established in German hospitals. Large differences among medical specialties exist and warrant further investigation.
\end{abstract}

Keywords: Hand hygiene; alcohol-based hand rub consumption, Compliance, Aktion Saubere Hände, Campaign, Patient safety; surveillance; Germany

\footnotetext{
*Correspondence: tobias.kramer@charite.de

${ }^{\dagger}$ Tobias Siegfried Kramer and Janine Walter contributed equally to this work.

${ }^{1}$ Institute for Hygiene and Environmental Medicine Charité-

Universitätsmedizin Berlin, Berlin, Germany

${ }^{2}$ National Reference Center for Surveillance of Nosocomial Infections,

Hindenburgdamm 27 in, 12203 Berlin, Germany

Full list of author information is available at the end of the article
}

(c) The Author(s). 2021 Open Access This article is licensed under a Creative Commons Attribution 4.0 International License, which permits use, sharing, adaptation, distribution and reproduction in any medium or format, as long as you give appropriate credit to the original author(s) and the source, provide a link to the Creative Commons licence, and indicate if changes were made. The images or other third party material in this article are included in the article's Creative Commons licence, unless indicated otherwise in a credit line to the material. If material is not included in the article's Creative Commons licence and your intended use is not permitted by statutory regulation or exceeds the permitted use, you will need to obtain permission directly from the copyright holder. To view a copy of this licence, visit http://creativecommons.org/licenses/by/4.0/ The Creative Commons Public Domain Dedication waiver (http://creativecommons.org/publicdomain/zero/1.0/) applies to the data made available in this article, unless otherwise stated in a credit line to the data. 


\section{Background}

Hand hygiene is one of the most effective measures for preventing healthcare-associated infections and the transmission of multidrug-resistant organisms [1, 2]. Adherence to the 5 Moments of Hand Hygiene remains of key importance for patient safety. However, reported compliance varies greatly [3]. Despite technical innovations and relevant limitations, direct observation based on the WHO protocol remains the gold standard [4]. Directly observed compliance rates are prone to the Hawthorne effect, overestimating performance [5]. Especially in overt observations improved compliance with hand hygiene can be occur in health care workers [6, 7]. In addition, this approach is time and resource intensive and might be difficult to implement in some centers [8]. Therefore, additional methods have proved necessary and have since been established. Consumption of alcohol-based hand rub (AHC) is used as a surrogate parameter for frequency of hand hygiene in various healthcare systems [9]. Application and interpretation of data can be difficult and has some pitfalls. The validity of $\mathrm{AHC}$ as a proxy for compliance with the 5 Moments model has not been conclusively established despite promising results [10]. While some reports describe a correlation with compliance on non-ICU inpatient wards $[11,12]$, others find no correlation between AHC and directly observed compliance [10]. Nonetheless, it provides opportunities for benchmarking and for additional feedback which is a key strategy for the improvement of hand hygiene compliance [13, 14].

In 2008 the national campaign for the improvement of hand hygiene in health care facilities ('Aktion Saubere Hände') was launched in Germany. The campaign is ongoing. After a validation period, a surveillance module for alcohol-based hand rub consumption (AHC) was introduced in 2007 [15]. Documentation of consumption of alcohol-based hand rub on the ward level remained one of the mandatory elements for participation in the campaign [16] and is recommended in the official national hand hygiene guidelines for healthcare settings [17]. The number of participating hospitals has increased year by year. We previously reported an increase in AHC among wards that reported continuously every year between 2007 and 2015 [16].

The objective of this study was to show development of alcohol-based hand rub consumption in the period from 2007 until 2018in all wards and institutions that reported their rates of consumption.

\section{Materials and methods}

The data presented in this study was derived from the voluntary German surveillance system for hand hygiene in health care institutions (HAND-KISS). Data on AHC and patient days (PD) was recorded by trained and designated infection prevention and control staff and submitted on an annual basis for every ward in each participating hospital. Data was aggregated based on HAND-KISS protocols and stratified into intensive care units (ICU), intermediate care units (IMC) and regular wards (RW) as well as by medical specialty, such as medical, surgical, pediatric and others $[15,16]$. Specific information on the methodology of HAND-KISS and the calculation of reference data has been described in detail previously $[16,18]$. All wards that provided data during the study period were included. Wards that provided annual data on AHC continuously during the study period 2007-2018 were included as the core group (CG) in this analysis.

AHC was calculated in milliliters $(\mathrm{mL})$ per PD. The statistical significance of a change in AHC was determined using the Wilcox sign rank sum test. A $p$-value of $<.05$ was considered significant. Furthermore, AHC of ICU-CGs and RW-CGs were grouped separately into quartiles (Q) of baseline consumption in 2007 (Q1 $\leq$ 25\%; Q2,> 25 to $\leq 50 \%$; Q3, > 50 to $\leq 75 \%$; Q4 > 75) in order to describe differences in their development.

The data utilised for this publication were anonymised or anonymized and collected in alignment with paragraph 23 the German Protection against Infection Act ("Infektionsschutzgesetz"). According this hospitals are required to routinely collect data on HAIs and aspects of HAI-prevention. Additional ethical approval and informed consent were therefore not required.

\section{Results}

In 2018, a total 1460 hospitals reported AHC in 17,330 wards (14,857 RW, 1998 ICU and 475 IMC). A total 108 of 181 hospitals that participated in 2007 still had wards participating in CG and reporting annual data on AHC in 2018 (Table 1).

Annual data on AHC which was included in the analysis covered 16,213,364 PD in 2007 and covered 77,325,205 PD in 2018 (Table 2).

Significant increases in AHC were reported during the study period. However, differences in the development were observed in different types of wards (Fig. 1).

Median AHC increased from $70.6 \mathrm{ml} / \mathrm{PD}$ (IQR: 52.597.74) to $129.4 \mathrm{ml} / \mathrm{PD}$ (IQR: $102.5-160.9)$ on ICUs (1.74 fold; 95\%CI 1.71, 1.76; $p<.0001)$. Median AHC increased on IMCs from $39.6 \mathrm{ml} / \mathrm{PD}$ (IQR: 16.1-52.8) to $64.0 \mathrm{ml} / \mathrm{PD}$ (IQR: 45.3-93.0) (1.69 fold; 95\%CI 1.60, $1.79 ; p<.0001)$. On regular wards median $\mathrm{AHC}$ was $14.45 \mathrm{ml} / \mathrm{PD}$ (IQR: 10.2.-20.6) in 2007 and increased to $28.8 \mathrm{ml} / \mathrm{PD}$ (IQR: 22.0-33.5) in 2018 (1.71 fold; 95\%CI $1.70,1.73 ; \mathrm{p}<.0001)$. This development also applied to all types of wards in the core group (GC). ICU-CGs and RW-CGs had higher median AHC in 2018 compared to total participating ICUs and RWs. 
Table 1 Description of participating wards providing data in 2018

\begin{tabular}{|c|c|c|c|c|c|c|c|c|}
\hline & \multicolumn{2}{|l|}{ total } & \multicolumn{2}{|l|}{ ICU } & \multicolumn{2}{|l|}{ IMC } & \multicolumn{2}{|l|}{ RW } \\
\hline & $\begin{array}{l}\text { All } \\
\mathrm{n}=\end{array}$ & $\begin{array}{l}\text { Core group } \\
n=\end{array}$ & $\begin{array}{l}\text { All } \\
\mathrm{n}=\end{array}$ & $\begin{array}{l}\text { Core group } \\
n=\end{array}$ & $\begin{array}{l}\text { All } \\
\mathrm{n}=\end{array}$ & $\begin{array}{l}\text { Core group } \\
n=\end{array}$ & $\begin{array}{l}\text { All } \\
\mathrm{n}=\end{array}$ & $\begin{array}{l}\text { Core group } \\
\mathrm{n}=\end{array}$ \\
\hline Hospitals & 1460 & 108 & 1083 & 82 & 321 & 16 & 1448 & 99 \\
\hline Wards & 17,330 & 912 & 1998 & 134 & 475 & 18 & 14,857 & 760 \\
\hline surgical & 2846 & 165 & 224 & 15 & 39 & 1 & 2583 & 149 \\
\hline interdisciplinary & 3075 & 138 & 1018 & 64 & 184 & 9 & 1873 & 65 \\
\hline medical & 3583 & 207 & 255 & 20 & 68 & 1 & 3260 & 186 \\
\hline neonatology & 255 & 21 & 186 & 16 & 16 & 1 & 53 & 4 \\
\hline pediatric & 760 & 58 & 82 & 8 & 13 & 0 & 665 & 50 \\
\hline rehabilitation & 488 & 3 & 15 & 0 & 4 & 0 & 469 & 3 \\
\hline Other non-surgical & 3204 & 135 & 111 & 3 & 97 & 4 & 2996 & 128 \\
\hline Other surgical & 3075 & 184 & 105 & 8 & 53 & 2 & 2917 & 174 \\
\hline Undefined & 44 & 1 & 2 & 0 & 1 & 0 & 41 & 1 \\
\hline patientdays & $866,974,407$ & $82,559,533$ & $49,144,866$ & $6,432,414$ & $9,549,448$ & 765,479 & $808,280,093$ & $75,361,640$ \\
\hline $\begin{array}{l}\text { Annual consumption } \\
\text { of AHC (liters) }\end{array}$ & $24,386,016$ & $2,747,782$ & $5,535,140$ & 732,170 & 579,661 & 34,887 & $18,271,214$ & $1,980,725$ \\
\hline
\end{tabular}

ICU Intensive care unit, IMC intermediate care unit, $R W$ regular ward, $A H C$ alcohol-based hand rub consumption

In addition, ICU-CGs with AHC in the lowest quartile in 2007 had the largest increase among ICUs, while it was slightly lower for the wards in the second and third quartiles (Fig. 2a).

Participating RW-CGs that began AHC in the lowest quartile had the largest increase over time. This also applied to wards in the second, third and fourth quartiles (Fig. 2b).

In 2018 wards caring for adult patients had lower AHC than wards caring for pediatric or neonatal patient populations (Table 3). Overall, median AHC was 129 ml/PD (IQR: 103-161) on ICUs while median AHC was $162 \mathrm{ml} / \mathrm{PD}$ (IQR: 129-216) on neonatal ICUs. Median AHC in pediatric wards on RWs was $30 \mathrm{ml} / \mathrm{PD}$ higher then overall median AHC on RWs.

\section{Discussion}

Of 1942 acute care hospitals in Germany [19], 1460 provided data on AHC (75.2\%). Between 2007 and 2018

Table 2 Change of annual alcohol-based hand rub consumption (AHC) 2007-2018

\begin{tabular}{|c|c|c|c|c|c|c|c|c|c|c|c|c|c|}
\hline \multirow{3}{*}{ Ward } & & \multirow{2}{*}{\multicolumn{2}{|c|}{ Patient days }} & \multirow{2}{*}{\multicolumn{2}{|c|}{$\begin{array}{l}\text { Annual consumption } \\
\text { of AHC (liters) }\end{array}$}} & \multicolumn{8}{|c|}{ Distribution of AHC consumption $\mathrm{ml} /$ patient day } \\
\hline & & & & & & \multicolumn{2}{|l|}{$\mathrm{MW}$} & \multicolumn{2}{|l|}{ P25 } & \multicolumn{2}{|l|}{ P50 } & \multicolumn{2}{|l|}{ P75 } \\
\hline & & $\begin{array}{l}\text { All } \\
n=\end{array}$ & $\begin{array}{l}\text { Core } \\
\mathrm{n}=\end{array}$ & $\begin{array}{l}\text { All } \\
n=\end{array}$ & $\begin{array}{l}\text { Core } \\
n=\end{array}$ & $\begin{array}{l}\text { All } \\
n=\end{array}$ & $\begin{array}{l}\text { Core } \\
\mathrm{n}=\end{array}$ & $\begin{array}{l}\text { All } \\
\mathrm{n}=\end{array}$ & $\begin{array}{l}\text { Core } \\
n=\end{array}$ & $\begin{array}{l}\text { All } \\
n=\end{array}$ & $\begin{array}{l}\text { Core } \\
\mathrm{n}=\end{array}$ & $\begin{array}{l}\text { All } \\
n=\end{array}$ & $\begin{array}{l}\text { Core } \\
\mathrm{n}=\end{array}$ \\
\hline \multirow[t]{4}{*}{$\overline{\mathrm{ICU}}$} & 2007 & $1,195,921$ & 518,160 & 92,208 & 40,394 & 79.2 & 76.8 & 52.5 & 53.3 & 70.6 & 71.9 & 97.74 & 92.9 \\
\hline & 2018 & $4,361,185$ & 536,980 & 594,276 & 79,602 & 137.4 & 147.0 & 102.5 & 117.6 & 129.4 & 137.4 & 160.9 & 171.3 \\
\hline & Chang & ye $[95 \% \mathrm{Cl}]$ & & & $1.97[1.96,1.98]$ & $1.74[1.71,1.76$ & $1.92[1.87,1.96]$ & & & & & & \\
\hline & $p$-valu & & & & & $<0.0001$ & $<0.0001$ & & & & & & \\
\hline \multirow[t]{4}{*}{ IMC } & 2007 & 125,599 & 68,745 & 5195 & 1666 & 41.4 & 24.2 & 16.1 & 14.7 & 39.6 & 24.2 & 52.8 & 40.7 \\
\hline & 2018 & $1,172,856$ & 55,878 & 82,854 & 3771 & 70.6 & 67.5 & 45.3 & 54.6 & 64.0 & 59.2 & 93.0 & 82.7 \\
\hline & Chang & ye $[95 \% \mathrm{Cl}]$ & & & $2.26[2.19,2.34]$ & $1.69[1.60,1.79]$ & $2.18[1.98,2.41]$ & & & & & & \\
\hline & $p$-valu & & & & & $<0.0001$ & 0.0003 & & & & & & \\
\hline \multirow[t]{4}{*}{ RW } & 2007 & $14,891,844$ & $6,363,820$ & 243,159 & 101,957 & 19.0 & 18.3 & 10.2 & 10.2 & 14.5 & 14.3 & 20.6 & 20.3 \\
\hline & 2018 & $71,791,164$ & $5,983,841$ & $2,112,330$ & 211,363 & 32.6 & 38.4 & 22.0 & 26.7 & 28.8 & 33.5 & 37.8 & 43.4 \\
\hline & Chang & ye $[95 \% \mathrm{Cl}]$ & & 8.69 & $2.07[2.06,2.08]$ & $1.71[1.70,1.73]$ & $2.10[2.06,2.14]$ & & & & & & \\
\hline & $p$-valu & & & & & $<0.0001$ & $<0.0001$ & & & & & & \\
\hline
\end{tabular}




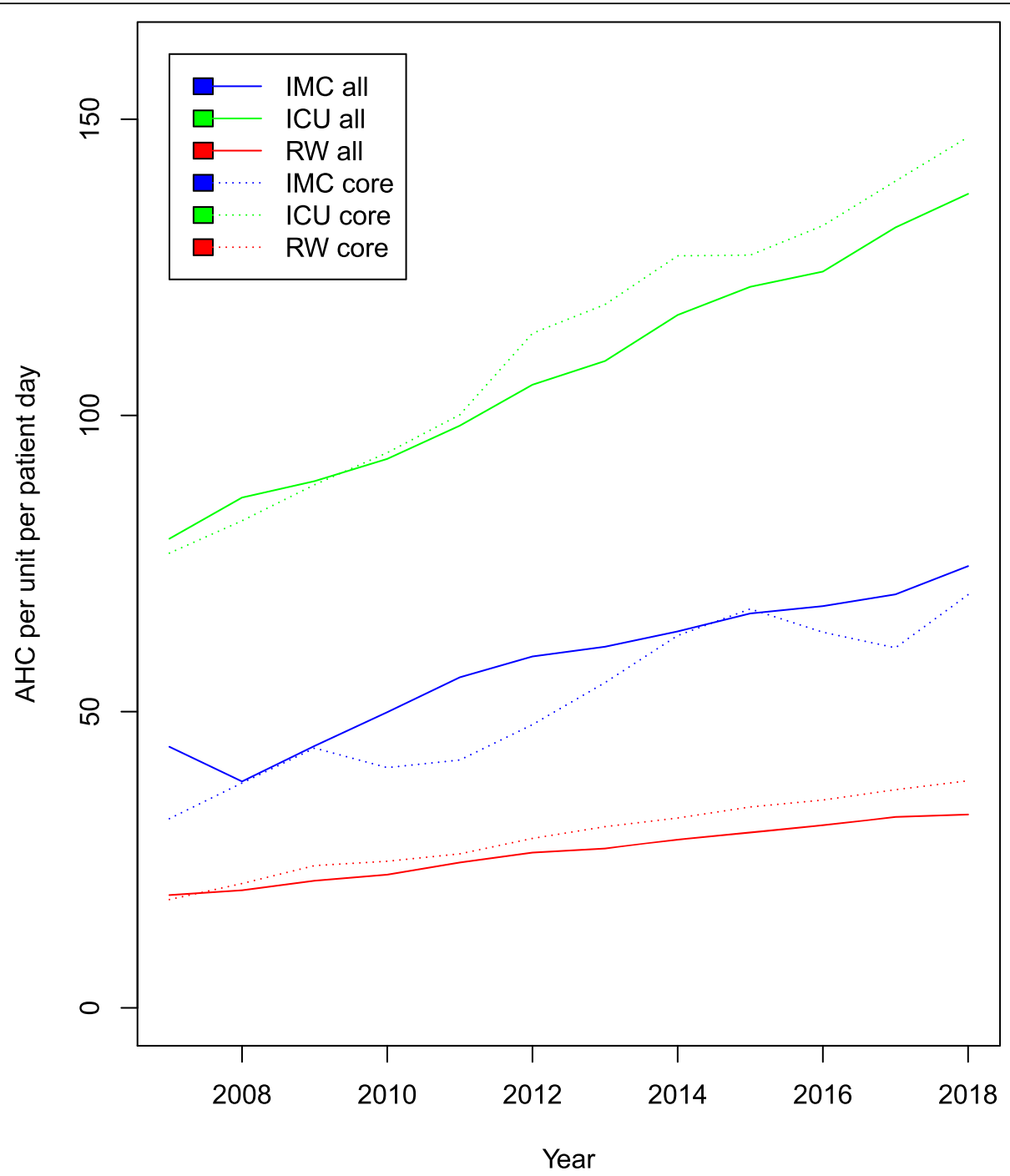

Fig. 1 Development of alcohol-based hand rub consumption (AHC) in ml/PD 2007-2018 in the individual types of wards of all participants (all) and the core group (core). ICU: Intensive care unit, IMC: intermediate care unit, RW: regular ward, AHC: alcohol-based hand rub consumption

median AHC increased almost two fold. We previously reported a similar increase in our CG [16]. However, the following results expand on this observation and cover all participating hospitals as well as wards in addition to the CG.

A recent point prevalence study found that median AHC was $20.3 \mathrm{ml} / \mathrm{PD}$ in European acute care hospitals (personal communication C. Suetens). This study also reported that ICUs in Europe had median AHC of $60 \mathrm{ml} / \mathrm{PD}$. In this study the representative sample of participating German acute care hospitals $(n=46)$ AHC was slightly above the median (20.0-29.9 ml/ PD). However, median AHC in all 218 German hospitals that participated in this point prevalence study was $35 \mathrm{ml} / \mathrm{PD}$ [20].

Reported AHC data on ward level from other campaigns or surveillance systems is scarce. Documentation and reporting of AHC is performed frequently in French hospitals. The mandatory ICSHA system documented an increase in median AHC from $6.1 \mathrm{ml} / \mathrm{PD}$ in 2006 [21] to an expected minimal consumption of $129 \mathrm{ml} / \mathrm{PD}$ on ICUs and $30 \mathrm{ml} / \mathrm{PD}$ on regular medical wards [22]. These results are similar to those observed in our voluntary system.

In order to establish reliable benchmarks, results need to be comparable [16]. Invasive treatment in ICU settings probably presents additional opportunities for hand hygiene which would result in higher AHC [18]. For this reason, participating wards have been stratified into ICU, IMC and RW, and further subdivided by medical specialty enabling valid assessment of the individual ward by the local IPC-team. The need for this stratification is especially apparent when comparing neonatal and pediatric ICUs with adult ICUs. Not only higher AHC, but also 


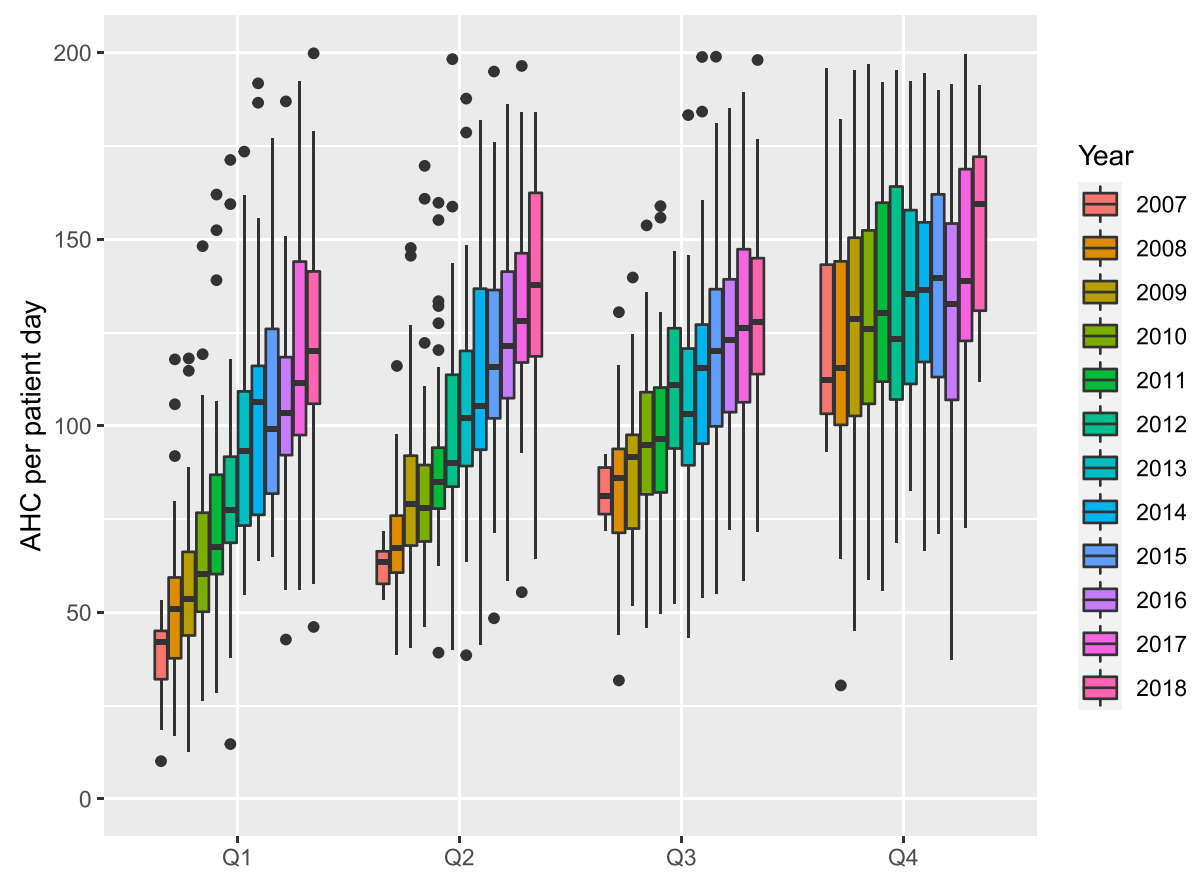

a

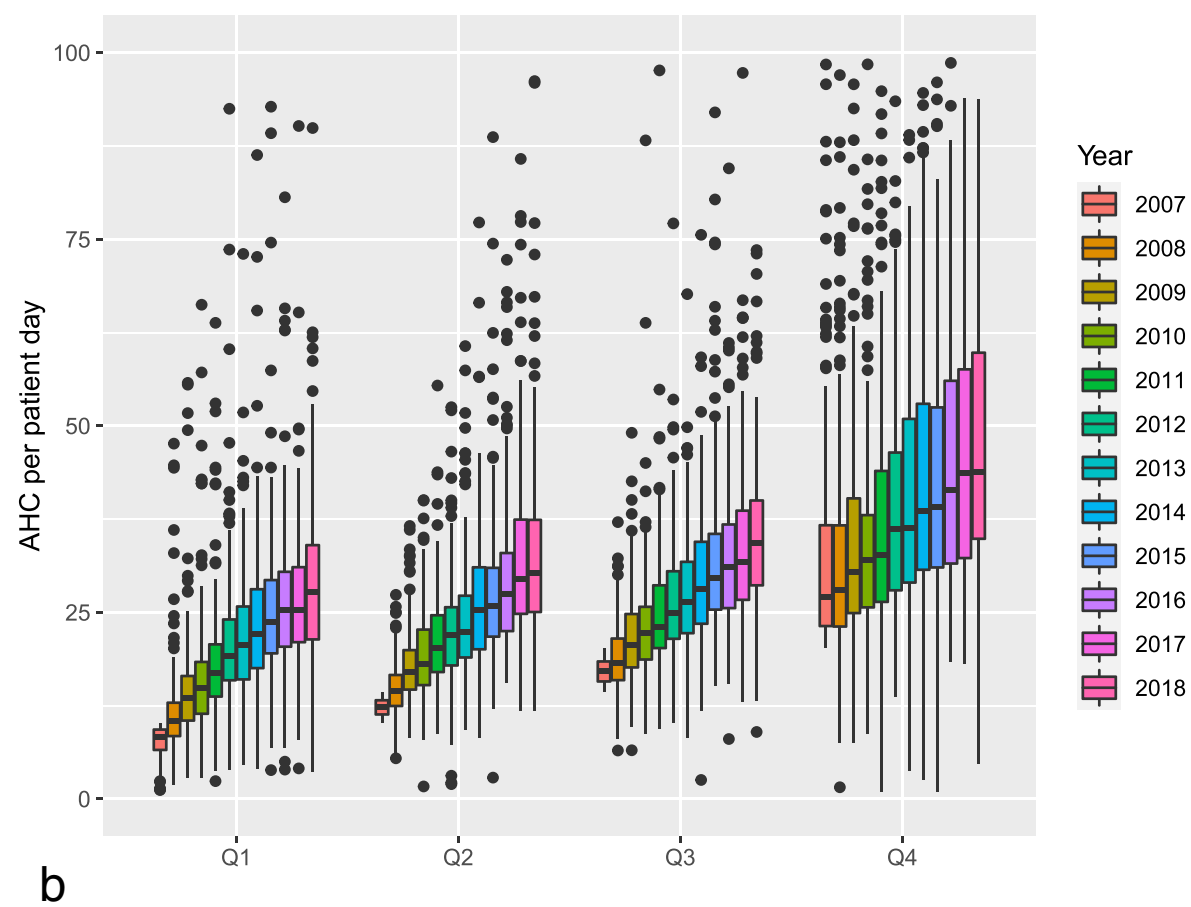

Fig. 2 Development of annual alcohol-based hand rub consumption (AHC) in ml/PD 2007-2018 in core group dependant on quartile of the initial consumption in Intensive care units (a) and regular wards (b). Q: quartile

higher rates of compliance were reported in these wards. The underlying reasons are not yet fully understood.

The cause of the increase in AHC in German hospitals is probably multifactorial. Between 2008 until 2018, the national hand-hygiene campaign 'Aktion-Saubere Hände' launched annual initiatives focused on various topics related to hand hygiene. They provided a stream of new teaching and educational materials, successfully introduced a system for a certification procedure, and established direct observation [23]. These were adapted by 
Table 3 Distribution of alcohol-based hand rub consumption (AHC) according to type of ward and specialty

\begin{tabular}{|c|c|c|c|c|c|c|}
\hline \multirow[b]{2}{*}{ Ward } & \multirow[b]{2}{*}{ Patient days } & \multirow[b]{2}{*}{ Annual consumption of AHC (liters) } & \multicolumn{4}{|c|}{ Distribution of AHC consumption $\mathrm{ml} /$ patient day } \\
\hline & & & mean & 25th percentile & median & 75th percentile \\
\hline \multicolumn{7}{|l|}{ ICU } \\
\hline total & $4,361,185$ & 594,276 & 136 & 103 & 129 & 161 \\
\hline surgical & 550,586 & 83,332 & 151 & 119 & 144 & 176 \\
\hline interdisciplinary & $2,244,321$ & 281,303 & 125 & 98 & 124 & 147 \\
\hline medical & 486,144 & 65,277 & 134 & 103 & 126 & 162 \\
\hline neonatology & 415,916 & 73,178 & 176 & 129 & 162 & 216 \\
\hline pediatric & 146,714 & 24,788 & 169 & 130 & 164 & 213 \\
\hline rehabilitation & 32,561 & 3471 & 107 & 103 & 111 & 120 \\
\hline \multicolumn{7}{|l|}{ IMC } \\
\hline total & $1,172,856$ & 82,854 & 71 & 45 & 64 & 93 \\
\hline surgical & 82,205 & 5983 & 73 & 48 & 62 & 89 \\
\hline interdisciplinary & 500,670 & 36,218 & 72 & 48 & 69 & 95 \\
\hline medical & 186,789 & 12,321 & 66 & 46 & 59 & 89 \\
\hline neonatology & 30,700 & 2896 & 94 & 72 & 88 & 133 \\
\hline pediatric & 15,860 & 2340 & 148 & 44 & 160 & 187 \\
\hline rehabilitation & 12,740 & 748 & 59 & 53 & 62 & 71 \\
\hline \multicolumn{7}{|l|}{ RW } \\
\hline total & $71,792,092$ & $2,112,330$ & 29 & 22 & 29 & 38 \\
\hline surgical & $12,840,675$ & 379,371 & 30 & 22 & 28 & 35 \\
\hline interdisciplinary & $9,154,385$ & 262,671 & 29 & 23 & 29 & 37 \\
\hline medical & $16,671,719$ & 493,922 & 30 & 23 & 29 & 37 \\
\hline neonatology & 117,162 & 10,318 & 88 & 53 & 77 & 114 \\
\hline pediatric & $1,905,292$ & 118,762 & 62 & 44 & 59 & 80 \\
\hline rehabilitation & $4,187,022$ & 63,967 & 15 & 11 & 19 & 28 \\
\hline
\end{tabular}

ICU Intensive care unit, IMC intermediate care unit, $R W$ regular ward, $A H C$ alcohol-based hand rub consumption

many participating institutions and raised public awareness, which might also have had an influence. The increase in $\mathrm{AHC}$ in our cohort was independent of the type of ward but it was especially evident in RWs. The positive development was observed most prominently but not exclusively in CG wards. AHC increased more over time, especially on wards which had lower AHC in 2007. These findings suggest the effectiveness of a long-term campaign on hand hygiene when combined with a voluntary surveillance system and the benefit of benchmarking and feedback by local infection prevention and control staff.

Several limitations apply to this study. Due to the voluntary nature of our surveillance system, it is possible that only highly motivated institutions participated. Continuous documentation of $\mathrm{AHC}$, annual interpretation of results, and the implementation of measures for improvement are mandatory legal requirements for healthcare institutions in Germany. A majority of hospitals in Germany have opted to use our surveillance system. Therefore, selection processes appear less important for the external validity of the data.
It is possible that changing features of the patient populations and changes in the structure of hospitals had an influence on AHC. Nevertheless, the increase in AHC was seen in wards in CGs that did not change over time.

The correlation of AHC and compliance is not fully clear. Therefore, AHC can only be a surrogate of compliance to the 5 Moments of Hand Hygiene on ward level. It is possible that uptake and availability of AHC improved but that compliance did not. An increase in AHC and, therefore, also of hand disinfections performed per patient-day only reflect a fraction of the hand hygiene opportunities occurring on wards [24]. The nearly two fold increase in AHC is certainly not associated with a two-fold increase in compliance [23]. Direct overt observation of hand hygiene compliance provides only a little insight into daily practice, which is subject to uncertainties [25]. Documentation of $\mathrm{AHC} / \mathrm{PD}$ allows for an easy and cost effective approach for a surrogate, providing a context for the results of direct observation. 


\section{Conclusions}

Consumption of alcohol-based hand rub increased between 2007 and 2018 on every type of ward that participated. The increase in AHC was even higher in wards that started in the lower quartiles of distribution. Surveillance of AHC is now widely established in German hospitals as a tool for providing feedback. Further research is necessary to determine the underlying reasons for differences among specialties and the efficacy of feedback on AHC on the quality of hand hygiene as well as on compliance with the WHO 5 Moments of Hand Hygiene.

\section{Abbreviations}

95\% Cl: 95\% Confidence interval; AHC: Alcohol-based handrub consumption; ASH: Aktion saubere hände (national hand hygiene campaign); CG: Core group; HAND-KISS: National hospital hand hygiene surveillance system; ICU: Intensive care unit; IMC: Intermediate care unit; IQR: Interquartile range; ml: Milliliters; OR: Odds ratio; PD: Patient days; Q: Quartile; RW : Regular ward

\section{Acknowledgements}

We would like to thank all the participants of HAND-KISS for their work and contribution.

\section{Authors' contributions}

JW, KB and TSK were responsible for the study design. JW, PG and CR supervised the Study. MB and JC were responsible for data collection and data cleaning. CS conducted the statistical analysis. TSK, KB and JW wrote the manuscript. All authors interpreted the data, provided important intellectual content, and revised the manuscript critically. All authors read and approved the final manuscript.

\section{Funding}

Publications fees were funded by the German Research Foundation (DFG) and the Open Access Publication Funds of Charité-Universitätsmedizin Berlin. Open Access funding enabled and organized by Projekt DEAL.

\section{Availability of data and materials}

The datasets used and/or analyzed during the current study are available from the corresponding author on reasonable request.

\section{Declarations}

\section{Ethics approval and consent to participate}

For this study, we analyzed aggregated and anonymous data that were collected by hospitals in accordance with Section 23 of the German "Protection against Infection Act,". Therefore, ethical approval and informed consent were not required and institutional review boards were not consulted.

\section{Consent for publication}

Not applicable.

\section{Competing interests}

The authors declare that they have no competing interests.

\author{
Author details \\ ${ }^{1}$ Institute for Hygiene and Environmental Medicine Charité- \\ Universitätsmedizin Berlin, Berlin, Germany. ${ }^{2}$ National Reference Center for \\ Surveillance of Nosocomial Infections, Hindenburgdamm 27 in, 12203 Berlin, \\ Germany. ${ }^{3}$ Aktion Saubere Hände Charité Universitätsmedizin Berlin, Berlin, \\ Germany.
}

Received: 20 October 2020 Accepted: 12 July 2021

Published online: 06 August 2021

\section{References}

1. Pittet D, Allegranzi B, Sax H, Dharan S, Pessoa-Silva CL, Donaldson L, et al. Evidence-based model for hand transmission during patient care and the role of improved practices. Lancet Infect Dis. 2006;6(10):641-52. https://doi. org/10.1016/S1473-3099(06)70600-4.

2. Allegranzi B, Pittet D. Role of hand hygiene in healthcare-associated infection prevention. J Hosp Infect. 2009;73(4):305-15. https://doi.org/10.101 6/j.jhin.2009.04.019.

3. Wetzker W, Bunte-Schonberger K, Walter J, Pilarski G, Gastmeier P, Reichardt C. Compliance with hand hygiene: reference data from the national hand hygiene campaign in Germany. J Hosp Infect. 2016;92(4):328-31. https://doi. org/10.1016/j.jhin.2016.01.022.

4. Sax H, Allegranzi B, Chraiti MN, Boyce J, Larson E, Pittet D. The World Health Organization hand hygiene observation method. Am J Infect Control. 2009; 37(10):827-34. https://doi.org/10.1016/j.ajic.2009.07.003.

5. Hagel S, Reischke J, Kesselmeier M, Winning J, Gastmeier P, Brunkhorst FM, et al. Quantifying the Hawthorne effect in hand hygiene compliance through comparing direct observation with automated hand hygiene monitoring. Infect Control Hosp Epidemiol. 2015;36(8):957-62. https://doi. org/10.1017/ice.2015.93.

6. Purssell E, Drey N, Chudleigh J, Creedon S, Gould DJ. The Hawthorne effect on adherence to hand hygiene in patient care. J Hosp Infect. 2020;106(2): 311-7. https://doi.org/10.1016/j.jhin.2020.07.028.

7. Kovacs-Litman A, Wong K, Shojania KG, Callery S, Vearncombe M, Leis JA. Do physicians clean their hands? Insights from a covert observational study. J Hosp Med. 2016;11(12):862-4. https://doi.org/10.1002/jhm.2632.

8. Larson E. Monitoring hand hygiene: meaningless, harmful, or helpful? Am J Infect Control. 2013;41(5 Suppl):S42-5. https://doi.org/10.1016/j.ajic.2012.09.029.

9. Hansen S, Schwab F, Gastmeier P, Group Ps, Pittet D, Zingg W, et al. provision and consumption of alcohol-based hand rubs in European hospitals. Clin Microbiol Infect. 2015;21(12):1047-51. https:/doi.org/10.1016/ j.cmi.2015.09.019.

10. Borg MA, Brincat A. Addressing the controversy of $100 \%$ hand hygiene compliance: can alcohol rub consumption data serve as a useful proxy validator? J Hosp Infect. 2018;100(2):218-9. https://doi.org/10.1016/j.jhin.201 8.04.024.

11. Haubitz S, Atkinson A, Kaspar T, Nydegger D, Eichenberger A, Sommerstein R, et al. Handrub consumption mirrors hand hygiene compliance. Infect Control Hosp Epidemiol. 2016;37(6):707-10. https:/doi.org/10.1017/ice.2016.47.

12. Branch-Elliman W, Snyder GM, King AD, Baldini LM, Dooley KM, Yassa DS, et al. Correlation of hand hygiene compliance measured by direct observation with estimates obtained from product usage. Infect Control Hosp Epidemiol. 2018;39(6):746-9. https://doi.org/10.1017/ice.2018.70.

13. Gould DJ, Moralejo D, Drey N, Chudleigh JH, Taljaard M. Interventions to improve hand hygiene compliance in patient care. Cochrane Database Syst Rev. 2017;9:CD005186.

14. Ivers N, Jamtvedt G, Flottorp S, Young JM, Odgaard-Jensen J, French SD, et al. Audit and feedback: effects on professional practice and healthcare outcomes. Cochrane Database Syst Rev. 2012;6:CD000259.

15. Behnke M, Gastmeier P, Geffers C, Monch N, Reichardt C. Establishment of a national surveillance system for alcohol-based hand rub consumption and change in consumption over 4 years. Infect Control Hosp Epidemiol. 2012; 33(6):618-20. https://doi.org/10.1086/665729.

16. Wetzker W, Walter J, Bunte-Schonberger K, Schwab F, Behnke M, Gastmeier $P$, et al. Hand rub consumption has almost doubled in 132 German hospitals over 9 years. Infect Control Hosp Epidemiol. 2017;38(7):870-2. https://doi.org/10.1017/ice.2017.71.

17. Händehygiene in Einrichtungen des Gesundheitswesens. Empfehlung der Kommission für Krankenhaushygiene und Infektionsprävention (KRINKO) beim Robert Koch-Institut (RKI). Bundesgesundheitsblatt Gesundheitsforschung, Gesundheitsschutz. 2016;59(9):1189-220.

18. Wetzker W, Bunte-Schonberger K, Walter J, Schroder C, Gastmeier P, Reichardt C. Use of ventilator utilization ratio for stratifying alcohol-based hand-rub consumption data to improve surveillance on intensive care units. J Hosp Infect. 2017;95(2):185-8. https://doi.org/10.1016/j.jhin.2016.10.020.

19. Gesellschaft DK. 2019. https://www.dkgev.de/fileadmin/default/Media pool/3_Service/3.2._Zahlen-Fakten/Eckdaten_Krankenhausstatistik.pdf.

20. https://www.nrz-hygiene.de/fileadmin/nrz/download/pps2016/PPS_2016_A bschlussbericht_20.07.2017.pdf.

21. Grammatico-Guillon L, Thiolet JM, Bernillon P, Coignard B, Khoshnood B, Desenclos JC. Relationship between the prevalence of methicillin-resistant Staphylococcus aureus infection and indicators of nosocomial infection control measures: a population-based study in French hospitals. Infect Control Hosp Epidemiol. 2009;30(9):861-9. https://doi.org/10.1086/599774. 
22. https://www.has-sante.fr/upload/docs/application/pdf/2019-04/grille_de_ recueil_icsha.3_2019.pdf.

23. Kramer TS, Bunte K, Schroder C, Behnke M, Clausmeyer J, Reichardt C, et al. No increase in compliance before aseptic procedures in German hospitals. A longitudinal study with data from the national surveillance system over four years. J Hosp Infect. 2020;106(1):71-5. https://doi.org/10.1016/j.jhin.202 007.001 .

24. Kolola T, Gezahegn T. A twenty-four-hour observational study of hand hygiene compliance among health-care workers in Debre Berhan referral hospital, Ethiopia. Antimicrob Resist Infect Control. 2017;6(1):109. https://doi. org/10.1186/s13756-017-0268-y.

25. Wu KS, Lee SS, Chen JK, Chen YS, Tsai HC, Chen YJ, et al. Identifying heterogeneity in the Hawthorne effect on hand hygiene observation: a cohort study of overtly and covertly observed results. BMC Infect Dis. 2018; 18(1):369. https://doi.org/10.1186/s12879-018-3292-5.

\section{Publisher's Note}

Springer Nature remains neutral with regard to jurisdictional claims in published maps and institutional affiliations.

Ready to submit your research? Choose BMC and benefit from:

- fast, convenient online submission

- thorough peer review by experienced researchers in your field

- rapid publication on acceptance

- support for research data, including large and complex data types

- gold Open Access which fosters wider collaboration and increased citations

- maximum visibility for your research: over $100 \mathrm{M}$ website views per year

At BMC, research is always in progress.

Learn more biomedcentral.com/submissions 